\title{
PURIFICATION AND BIOCHEMICAL CHARACTERIZATION OF A T/TN SPECIFIC LECTIN FROM LEPECHINIA BULLATA SEEDS (LAMIACEAE)
}

\author{
WILCHES-TORRES A. ${ }^{1,2}$, ROJAS-CARABALLO J. ${ }^{1,5}$, SANABRIA E. ${ }^{1}$, REYES-MONTANO E. ${ }^{1}$, FERNÁNDEZ-ALONSO J. \\ L. ${ }^{1,3}$, VARROT A. ${ }^{4}$, IMBERTY A. ${ }^{4}$, VEGA N. ${ }^{*}$
}

${ }^{1}$ Universidad Nacional de Colombia, Bogotá, Chemistry Department, Protein Research Group Bogotá Colombia, ${ }^{2}$ Núcleo Research Group: Universidad de Boyacá, Colombia, ${ }^{3}$ Real Jardín Botanico CSIC, Biodiversity and Conservation Department, Plaza de Murillo 2, 28014 Madrid, España, ${ }^{4}$ University Grenoble Alpes, CNRS, CERMAV, F-38000 Grenoble, France, ${ }^{5}$ Centro de Investigación en Salud para el Trópico (CIST), Facultad de Medicina, Universidad Cooperativa de Colombia, Santa Marta, Colombia Email: navegac@unal.edu.co

Received: 21 Jul 2017 Revised and Accepted: 21 Sep 2017

\section{ABSTRACT}

Objective: This study focused on purifying and characterizing a lectin from Lepechinia bullata (L. bullata) seeds, and determining its specificity towards tumour-associated carbohydrate-antigens.

Methods: Pigments were removed by washing the seeds with $\mathrm{NH}_{4} \mathrm{OH} 0.1 \mathrm{M} \mathrm{pH} 9.4$ and treating the crude extracts with Pectinex®. The purification procedure consisted of anion exchange chromatography on diethylaminoethyl (DEAE)-Sephadex followed by affinity chromatography. For the characterization, the phase was used polyacrylamide gel electrophoresis-sodium dodecyl sulphate (SDS-PAGE), isoelectric focusing, hemagglutination assays, enzyme-linked lectinosorbent assay (ELLA) and thermal shift assay (TSA).

Results: $6.2 \mathrm{mg}$ of lectin were obtained from $100 \mathrm{~g}$ of seeds. It was able to agglutinate enzymatically treated erythrocytes with a minimal required lectin concentration of $7 \mu \mathrm{g}$. $\mathrm{ml}^{-1}$. Strong binding to asialo bovine submaxillary mucine (aBSM) was determined, corroborating Tn recognition.

The isoelectric focusing showed a unique band at $\mathrm{pH}$ 8.5. Lectin pure shown bands at 28, 48 and $93 \mathrm{kDa}$ by SDS-PAGE, with an incomplete dissociation of the last species despite trying several reduction conditions. By preparative electrophoresis under different conditions, three species were observed too, in all fractions one band at $28 \mathrm{kDa}$ on Tricine-PAGE in reducing and no reducing conditions were found.

Amino acid composition, carbohydrate content, thermal stability and $\mathrm{Ca}^{2+}$ and $\mathrm{Mn}^{2+}$ requirements were determined. $\mathrm{N}$-acetylgalactosamine (GalNAc) and desialylated mucins inhibited the agglutinant activity on human cells. Fetuin inhibited hemagglutination of rabbit erythrocytes.

Conclusion: A new lectin was isolated and characterized from L. bullata seeds, it recognizes T/Tn antigen and shows some similarities with other Lamiaceae lectins.

Keywords: Lamiaceae lectin, Lepechinia bullata, Protein, Purification, T/Tn antigen

(C) 2017 The Authors. Published by Innovare Academic Sciences Pvt Ltd. This is an open access article under the CC BY license (http://creativecommons.org/licenses/by/4.0/) DOI: http://dx.doi.org/10.22159/ijpps.2017v9i11.21514

\section{INTRODUCTION}

Lectins are widely distributed in nature where they can be found in viruses, bacteria, plants and animals. Those specific carbohydrate binding proteins are different from sugar-specific antibodies and enzymes as well as from sugar transport proteins [1]. Lectins present high potential as diagnostic tools for diseases associated with alterations in cellular glycosylation, as found in various cancers [2]. Several studies have been focused on the search for the tumor markers and their therapeutic alternatives. A special interest has given to the Thomsen-Friedenreich antigen ( $\mathrm{TF}$ or $\mathrm{T}$, galactose (Gal) $\beta 1,3$ GalNAc $\alpha$-0-serine (Ser)/threonine (Thr)) as well as to its precursor, the Tn antigen (GalNAc $\alpha$-O-Ser/Thr) and its sialylated forms (sTn), which are normally cryptic structures in the peptide core of 0-glycoproteins [3-8]. The expression of T, Tn and sTn antigens is associated with several carcinomas and allows, in some cases, the prognosis of the clinical course $[3,4]$. The importance of the Tn antigen and its expression in other disorders and diseases has recently been reviewed [6]. Thus, lectins able to recognize these structures are highly sought for in particular in plants [9]. However, Lamiaceae lectins have been little studied despite preliminary reports on their ability to recognize the Tn antigen [10-12].

Detailed studies have been carried out on a few Lamiaceae species from the Northern hemisphere's temperate zone until now [13-17] and the lectin from Salvia sclarea seeds (SSL) was the first to be isolated and partially characterized [14]. By contrast, species from the neotropical have been little explored despite their great diversity. A systematic survey has been conducted on species belonging to the neotropical subgenus Calosphace [18, 19] and certain species naturalized in the New World have also been investigated [20], some having commercial value. Given the abundance of Lamiaceae species in Colombia and the potential clinical applications [21], our group undertook a systematic search for the identification, isolation, and characterization of lectins from selected species with the determination of their biological activities $[20,22]$. The lectins from Salvia palifolia Kunth and Hyptis mutabilis (Rich.) Briq [23]. Have been partially characterized and a detailed work has been done with Salvia bogotensis Benth. lectin (SBoL) [24, 25]. The biochemical characterization of SBoL showed some differences with SSL although both lectins recognize specifically the Tn antigen.

Lamiaceae lectins isolated from nutlets (seeds) have shown some common features at the level of their molecular properties. They appear as dimers/tetramers close to neutral $\mathrm{pH}$. It is worth to notice that Moluccella laevis lectin (MLL) possess a unique structural arrangement, as the 67,42 and $26 \mathrm{kDa}$ subunits are present in the absence of reducing agents and only the $26 \mathrm{kDa}$ subunit is active after affinity chromatography in the presence of $8 \mathrm{M}$ urea [26]. They show a relatively high carbohydrate content and the structure of the $\mathrm{N}$-linked oligosaccharide (2-3 glycan/polypeptide chain) has been elucidated for SSL [16]. Preliminary evidence indicate a similar structure for the MLL oligosaccharide [27]; the analogous structure is also suggested in SBoL [25] which presents 3-4 oligosaccharide units per monomer. All characterized Lamiaceae lectins are basic proteins as determined by their experimental isoelectric point (pI) 
values. GalNAc is the most potent inhibitor amongst monosaccharides and they show high affinity for asialomucins such as asialo ovine submaxillary mucin (aOSM) or aBSM, which are the best erythroagglutinin inhibitors. Thus, those have been used efficiently as ligands in affinity chromatography.

Hitherto, the Vicia villosa isolectin $\mathrm{B} 4\left(\mathrm{VVB}_{4}\right)$ [28] from leguminosae family is the most specific one for detecting Tn antigen, this could hamper its use as a glycobiology tool. Limited structural information is available for lamiaceae lectins since their purification is difficult and does not give the substantial amount of pure protein necessary for its tertiary structure determination. Likewise, their sequence in nucleotides or amino acid is generally unknown which prevent their production in recombinant form.

In order to deepen the knowledge of Lamiaceae lectins, we chose the L. bullata species for this study, taking into account its endemic character, the availability of substantial amounts of seeds and its high lectin activity (85\%). The neotropical genus Lepechinia Wild. has 10 taxa in Colombia [20]. The objective of this work was to isolate and characterize L. bullata lectin (LBL) prior to the investigation on its interaction with Tn-bearing cells.

\section{MATERIALS AND METHODS}

\section{Chemicals and vegetal material}

The reference voucher of plant L. bullata species, from which seeds were collected (herbarium collection: COLO. Boyacá. Arcabuco-GachantiváJLF-557667 and COLO. Boyacá. Arcabuco-Gachantivá-JLF-557668) were deposited in the colombian national herbarium (COL). These correspond to the locality: outside road, $\mathrm{Km} 1.5$ (N 05 46.265'. W073 '28.266'. 2584 meters above sea level (MASL) and 4.5 (N $05^{\circ} 46.250^{\prime}$. W073 $28.244^{\circ}$. 2600 MASL, Arcabuco-Gachantivá (Boyacá, Colombia). Fresh human blood was obtained from the clinical laboratory of Universidad Nacional de Colombia, Boyatá. Animal erythrocytes were supplied by the haematology laboratory of the Veterinary Faculty (Universidad Nacional de Colombia, Boyatá). Rabbit red blood cells were obtained from BioMérieux Laboratories. BioRad equipment was used for chromatography and electrophoresis. Fetuin-Agarose and proteins used as standards were all from Sigma-Aldrich. Bovine submaxillary mucin (BSM) and ovine submaxillary mucin (OSM) were from Fluka. Sugars were commercial products having the highest available purity. The rest of reagents were analytical grade. Enzymes (neuraminidase, $\beta$ galactosidase, papain and trypsin) used for erythrocytes degradation were from Sigma-Aldrich.

\section{General methods}

Mature L. bullata seeds were grinded to a fine powder. With the resulting flour, non-protein nitrogen content was determined, according to Pérez et al. [29]. Carbohydrate inhibition, demetallization assays, neutral sugar and amino acid determination were performed according to the methods described in Pérez [30]. Protein quantification was carried out using the micro Kjeldahl method or bicinchoninic acid (BCA) assay [31, 32]. In demetallization assay, the lectin was dialyzed first against $50 \mathrm{mmol}$ ethylenediamine-tetraacetic acids (EDTA) and then against phosphate buffer saline (PBS) pH 7.3 \pm 1.0 .

\section{Lectin extraction}

Several procedures were assayed to remove pigments or to diminish their formation due to the high polyphenol content in seeds. The final procedure was as follows. In small-scale experiments, $1.0 \mathrm{~g}$ seeds were left to soak in $10 \mathrm{ml} \mathrm{NH}_{4} \mathrm{OH} 0.1 \mathrm{M} \mathrm{pH} 9.4$ for $1 \mathrm{~h}$ with continuous stirring at room temperature (RT), then, the seeds were dried at RT and left to soak in PBS $20 \mathrm{mmol}$ mmol NaCl-5 mmol thiourea, $\mathrm{pH}$ $7.3 \pm 1.0$ [33] for $2-3 \mathrm{~h}$, at $4{ }^{\circ} \mathrm{C}$ and were then macerated and extracted in PBS-5mmol thiourea with continuous stirring at $4^{\circ} \mathrm{C}$, for $8 \mathrm{~h}$. The extract, which had a viscous appearance, was centrifuged (38 000 gravities (xg), $1 \mathrm{~h}, 4^{\circ} \mathrm{C}$ ). The supernatant was recovered whilst this extraction procedure was reapplied three times on the pellet. Protein quantity and haemagglutination activity were determined immediately. The first extract was also treated with polygalacturonases mix (Pectinex囚) due to high viscosity as described below.
Larger scale extraction ( $50 \mathrm{~g}$ ) was done in PBS-5 mmol thiourea buffer with four successive extractions steps as described above. An aliquot (10-20 ml) of each extract was taken for nitrogen determination by micro-Kjeldahl. The extracted pool was extensively dialyzed against PBS-5 mmol thiourea buffer and tested for haemagglutination and lectin specificity was initially studied by ELLA.

\section{Pectinex ${ }^{\circledR}$ treatment}

Extract pH was adjusted to pH 4.7 with $200 \mathrm{mmol}$ acetate buffer. Pectinex ${ }^{\circledR}$ Ultra SP-L (Novo) was then added ( $40 \mu \mathrm{l} / 3 \mathrm{ml}$ extract); the solution was incubated overnight at $37 \pm 0.5^{\circ} \mathrm{C}$. The extract was centrifuged (38 $000 \mathrm{xg}, 1 \mathrm{~h}, 4{ }^{\circ} \mathrm{C}$ ), the supernatant was dialyzed against PBS pH 7.0 and lectin activity was determined. Control of experiments was made through dialysis and SDS-PAGE and no evidence of proteolytic activity in Pectinex $®$ was shown.

\section{LBL purification}

Protein purification was carried out using both ionic exchange chromatography (IEC) and affinity chromatography. Briefly, extracts were passed through a column $(2 \times 15 \mathrm{~cm})$ with DEAE-Sephadex resin (GE Healthcare) equilibrated in PBS. The non-retained peak (peak I) was obtained with PBS and was later used for affinity chromatography after concentration on Amicon® PM 10. Different affinity chromatography experimental conditions were assayed leading us to the following method: aBSM was prepared by digesting $50 \mathrm{mg}$ BSM (Sigma-Aldrich) in $0.01 \mathrm{~N} \mathrm{HCl}, 80^{\circ} \mathrm{C}, 1 \mathrm{~h}$; freeze-drying removed acid. The affinity supports were prepared by coupling aBSM to Sepharose $4 \mathrm{~B}$ following the general techniques [34], by using activated sepharose 4B (Sigma-Aldrich), cyanogen bromide (CNBr), N-hydroxysuccinimide (NHS) and 6-aminohexanoic acid $(\mathrm{ECH})$ (GE Healthcare) preactivated, following manufacturer specifications.

Lectin-active fractions coming off ultrafiltration were applied to the aBSM-Sepharose 4B column $(2 \times 19 \mathrm{~cm})$ equilibrated with PBS. The resin was washed with PBS prior elution with $50 \mathrm{mmol}$ tris (hydroxymethyl) aminomethane (Tris) $-\mathrm{OH} \mathrm{pH} \mathrm{11.4.100 \mu l} \mathrm{HCl} 2 \mathrm{~N}$ were added to the $1.0 \mathrm{ml}$ fractions to obtain a final $\mathrm{pH}$ close to neutrality. Fractions were pooled and extensively dialyzed against $20 \mathrm{mmol} \mathrm{NH}_{4} \mathrm{HCO}_{3}$ prior freeze-drying. Protein concentration, specific agglutination activity (SAA) and ELLA assays were carried out using PBS-dissolved protein. The resin's retention capacity was assessed by applying increasing amounts of pooled extracts and checking the presence of lectin in the flow-through.

\section{Polyacrylamide gel electrophoresis}

SDS-PAGE was performed in non-reducing and reducing conditions (dithiotreitol (DTT) $(40-100 \mathrm{mmol})$, heating $\left.100{ }^{\circ} \mathrm{C}, 10 \mathrm{~min}\right)$ on a $12.5 \%$ separating gel $(12.5 \% \mathrm{~T}, 2.7 \% \mathrm{C})$ according to Laemmli [35] or Schägger and Von Jagow [36], using 10-20 $\mu \mathrm{g}$ protein/well. As a molecular weight standard Opti-protein XL Marker ${ }^{\circledR}$ (ABM) was used, which has a protein range of 245 to $11 \mathrm{kDa}$; Precision Plus Protein Standards Unstained $\AA$ (Bio-Rad), with a range between 250 and $20 \mathrm{kDa}$; or a protein mixture of bovine serum albumin (BSA) (66 $\mathrm{kDa})$, ovalbumin $(45 \mathrm{kDa})$, carbonic anhydrase $(31 \mathrm{kDa}), \beta$ lactoglobulin $(18 \mathrm{kDa})$ and lysozyme $(14 \mathrm{kDa})$. The run was performed at 100 volts for $1.5 \mathrm{~h}$. Gels were stained using Coomassie G-250 or Instant blue (Expedeon) and later analyzed with the VersaDoc $®$ or Gel-Doc imager systems (Bio-Rad).

\section{Molecular weight}

Subunit relative molecular weight $(\mathrm{Mr})$ was determined by PAGE using Laemmli procedure [35]. $10 \mu \mathrm{g}$ of LBL were runned under reducing and non-reducing conditions. Native protein molecular weight was determined by preparative electrophoresis carried out according to the procedure described by Sánchez [37].

\section{Lectin detection assay}

Lectin activity was determined on crude extracts treated or nontreated with Pectinex $®$ and on purified protein by ELLA according to the previously described procedure [22, 38, 39]. 96 well plates (NUNC, F16 Maxisorp) were sensitized with aBSM $\left(0.14 \mu \mathrm{g} \cdot \mathrm{ml}^{-1}\right)$ and biotinylated $\mathrm{VVB}_{4}\left(1 \mathrm{mg} \cdot \mathrm{ml}^{-1}\right)$ was used as a specific control. 
Streptavidine-peroxidase $\left(1.3 \mu \mathrm{g} \cdot \mathrm{ml}^{-1}\right)$ and $\mathrm{H}_{2} \mathrm{O}_{2}-2,2^{\prime}$-azino-bis 3ethylbenzthiazoline-6-sulfonic acid (ABTS) were added after suitable washes and absorbance at $415 \mathrm{~nm}$ were read on a plate autoreader (Bio-Rad). The activity (\%) was calculated as

$$
\%=100-\left(\frac{\text { Sample absorbance }}{\text { Control absorbance }} \times 100\right)
$$

\section{Hemagglutination assay}

Assays were done on human and animal red blood cells (RBCs) as described in Pérez [30]. For A+human erythrocytes, the treatment described by Hirohashi at al. was used [40], RBCs were enzymatically treated to expose $\mathrm{T}$ or $\mathrm{Tn}$ determinants using neuraminidase and g-galactosidase stock at a concentration of $0.5 \mathrm{mg} \cdot \mathrm{ml}^{-1}$ in $1 \mathrm{X}$ PBS. Hemagglutinating activity was tested in presence and absence of 5-100 mmol $\mathrm{Ca}^{2+}$ and $\mathrm{Mn}^{2+}$ (chloride ions). The effect of temperature was assessed after incubating the lectin at $50 \mu \mathrm{g} \cdot \mathrm{ml}^{-1}$ in PBS for $1 \mathrm{~h}$ between $25-92{ }^{\circ} \mathrm{C}$. SAA was determined as being the minimal protein dilution required for agglutination.

For rabbit RBCs, a 4\% erythrocytes solution (bioMérieux, France) was prepared and treated with trypsin from porcine pancreas (Sigma-Aldrich), papain from papaya latex (Sigma-Aldrich), or a mixture of both enzymes. $2 \mathrm{ml}$ of $4 \%$ rabbit erythrocytes in 150 $\mathrm{mmol} \mathrm{NaCl}$ were mixed with $40 \mu \mathrm{l}$ of the enzyme stock solution $(0.02$ $\mathrm{mg}$ of enzyme) and incubated for $30 \mathrm{~min}$ at $37 \pm 0.5^{\circ} \mathrm{C}$. Three washes were then performed with $150 \mathrm{mmol} \mathrm{NaCl}$.

\section{Lectin thermostability}

The protein melting temperature was determined in a 96-well plate by TSA. The lectin was diluted at a concentration of $0.1,0.2$ and $0.5 \mathrm{mg} \cdot \mathrm{ml}^{-1}$ in PBS and 5X SYPRO Orange ${ }^{\circledR}$ (Bio-Rad) was added in a final volume of $25 \mu \mathrm{L}$. The samples were subjected to thermal denaturation in a real time polymerase chain reaction (PCR) machine (Mini Opticon, Bio-Rad) with a temperature gradient from 20 to $100{ }^{\circ} \mathrm{C}$ at a heating rate of $1{ }^{\circ} \mathrm{C} \mathrm{min}-1$. Protein unfolding was followed by the increase in the fluorescence values given by the SYPRO Orange probe (excitation 450-490 nm and detection 560-580 nm) [41]. Data were evaluated by CFX manager ${ }^{\circledR}$ software (Bio-Rad).

\section{Isoelectric focusing}

The $\mathrm{pI}$ was determined with a $3.5-10 \mathrm{pH}$ gradient in non-denaturing conditions following Bollag and Edelstein procedure [42].

\section{LBL biotinylation}

The lectin was biotinylated [43] with two successive additions of sulfobiotin-X-NHS (Calbiochem) (2:1 w/w, $12 \mathrm{~h}$ interval); excess biotin was removed by ultrafiltration using $10 \mathrm{kDa}$ Nanosep filters (Amicon Ultra-15 centrifugal filter devices).
Detection of Tn antigen in cell lines by cellular enzyme-linked immunospecific assay (CELISA)

MCF-7 (human breast adenocarcinoma) and HeLa (cervical cancer) cell-lines (ATCC) were used as positive targets for detecting Tn antigen. The cells were cultured in Dulbecco's modified eagle medium (DMEM), supplemented with $10 \%$ bovine fetal serum and antibiotics (50 U.ml-1penicillin; $50 \mathrm{~g} \cdot \mathrm{ml}^{-1}$ streptomycin and 25 ng. $\mathrm{ml}^{-1}$ amphotericin) at $37 \pm 0.5{ }^{\circ} \mathrm{C}$ in a humid atmosphere and $5 \%$ $\mathrm{CO}_{2}$. According to the described procedures [24, 44], cells culture $(10.000 /$ well) was fixed with $4 \%$ paraformaldehyde and then incubated with dilutions serial of biotinylated LBL. Streptavidineperoxidase (1:500) and $\mathrm{H}_{2} \mathrm{O}_{2}$-ABTS were added after suitable washes and finally, absorbance at $415 \mathrm{~nm}$ was read on a Bio-Rad ELISA auto reader. Biotinylated $\mathrm{VVB}_{4} 1 \mathrm{mg} / \mathrm{ml}$ was used as a control.

\section{Anti SBoL interaction with LBL}

The magnitude of interaction between immunoglubulin G (IgG) antiSBoL [24] and LBL was determined by ELLA. The plates (NUNC, F16 Maxisorp) were sensitized with LBL and SBoL $(15 \mu \mathrm{g} / \mathrm{ml})$ according to the methodology described by Pérez [22]. An IgG stock solution at 100 $\mu \mathrm{g} \cdot \mathrm{ml}^{-1}$ was used for serial dilutions until 100:1 of the final volume in each well. Interactions were detected with a secondary antibody (Anti$\mathrm{IgG}$ ) produced in goat and coupled to peroxidase (Sigma-Aldrich) using ABTS as substrate. Absorbance was measured at $415 \mathrm{~nm}$.

\section{RESULTS AND DISCUSSION}

\section{Lectin extraction}

L. bullata seeds have a black color and hence the protein extracts showed strong pigmentation. Removal of pigments prior protein extraction was, therefore, an essential step in the purification procedure. Different assays were carried out to this end; washing of seeds with a solution of $\mathrm{NH}_{4} \mathrm{OH}$ was the most effective. Most remaining pigments were removed using IEC on DEAE-Sephadex in a subsequent purification step. The best extraction results were obtained by including $5 \mathrm{mmol}$ thiourea to the PBS extraction buffer and in the dialysis solutions. It reduced the amount of polyphenols by inhibiting polyphenol oxidases [33] whilst keeping the lectin's activity unaltered ( $48 \%$ in the first extract).

The first extraction gave a very viscous solution presumably resulting from the presence of pectin-like polysaccharides known to be present in nearly all Lamiaceae species and which usually hamper lectin detection $[18,20,22,25]$. As observed in other studies $[18,20$, $25]$, digestion with Pectinex $\AA$ permitted to diminish the viscosity and to obtain a significant increase in lectin activity in each extract (table 1). In the first extract, LBL hemagglutination activity got from $48 \%$ without Pectinex $®$ treatment to $82 \%$ with. All extracts were pooled for the next purification steps. In hemagglutination assay using Tn erythrocytes, the lectin activity was better with crude extracts enzymatically treated (1st, 2nd, 3rd and 4th extracts) than with untreated extracts, showing larger clusters in the first case.

Table 1: ELLA assay activity of crude extracts from Lepechinia bullata seeds

\begin{tabular}{lll}
\hline Seeds & Lectin activity (\%) & Treatment pectinex ${ }^{\circledR}$ \\
\cline { 2 - 3 } extraction & Untreatment pectinex ${ }^{\circledR}$ & $82.0 \pm 2.1$ \\
\hline First extract & $48.2 \pm 1.3$ & $61.0 \pm 1.4$ \\
Second extract & $22.3 \pm 0.6$ & $45.0 \pm 0.9$ \\
Third extract & $10.7 \pm 0.4$ & $19.3 \pm 0.4$ \\
Fourth extract & - & $45.1 \pm 1.1$ \\
Pool of extracts & $34.2 \pm 0.8$ & \\
\hline
\end{tabular}

Values are means \pm standard deviations (SD) of three determinations.

A crude protein content of $14.4( \pm 1.1) \%$ in L. bullata seeds was obtained, which is higher than for seeds from $S$. bogotensis $(13.1 \%)$ and lower than for seeds from S. palifolia (15.7\%) and S. rubescens Kunth (19.6\%) [25].

In seeds from Amaranthus caudatus [45] and Sesamum indicum L [46], pertaining to another plants families, has been studied the protein content extracting in water, giving similar results in total protein amount (13.9\% and $14.7 \%$ respectively) than Lamiaceae species.
$\mathrm{NaCl}$ addition in extraction solution and $\mathrm{pH}$ variation increase the total protein quantity obtaining from seeds [47], however, in almost all cases, these protein isolates were used for protein identification only.

\section{Lectin purification}

Precipitation with ammonium sulphate and ethanol 96\% was assayed to purify LBL from the pool of extracts but the lectin was 
obtained in all fractions (data not shown). Contrary to SBoL [25] and SSL [14] which precipitated at $0-50 \%$ and $50-80 \%$ ethanol respectively, precipitation could not use as a purification step for
LBL. The extracts were therefore submitted to weak anion exchange chromatography on DEAE-sephadex with elution with 1 $\mathrm{M} \mathrm{NaCl}$ (fig. 1).
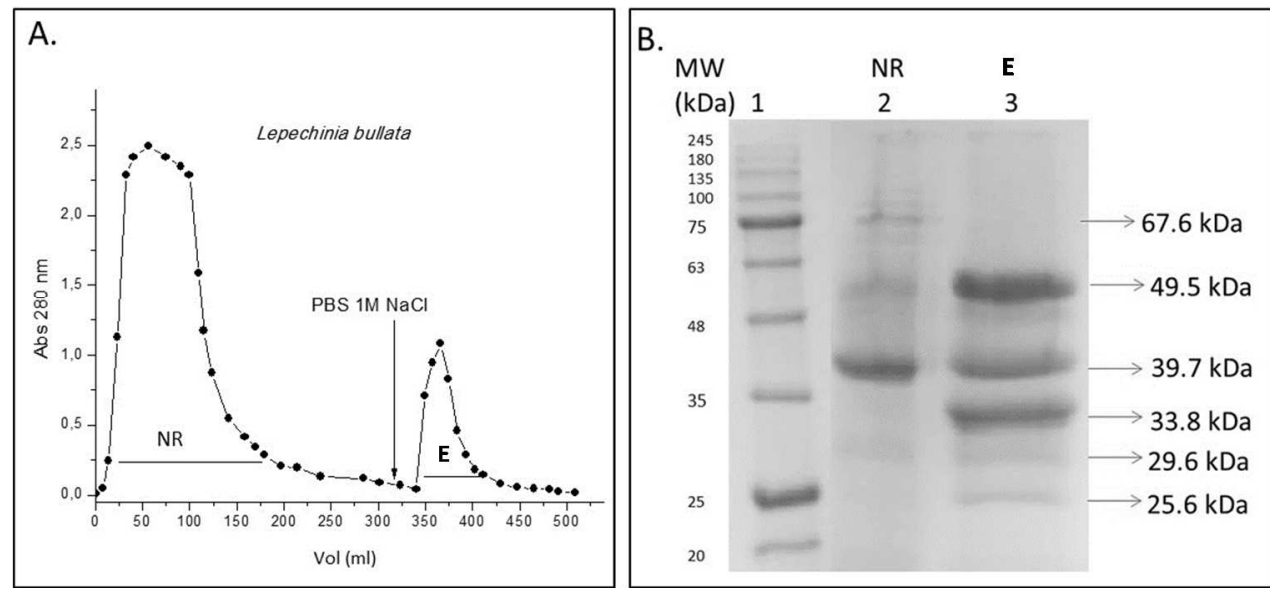

Fig. 1: Chromatographic profile and SDS-PAGE from fractions of $L$. bullata obtained by IEC. NR: Non-retained fraction. E: eluted fraction. MW: molecular weight standard. A. IEC profile at $280 \mathrm{~nm}$. B. 12.5\% tris-glycine SDS-PAGE on fractions from IEC. Lane 1. MW; lane 2. Non-retained fraction; lane 3. eluted fraction

The non-retained fraction exhibited hemagglutination on human erythrocytes only with exposed Tn, whilst there was no discrimination for the eluted fraction (table 2). However, both fractions agglutinated enzymatically treated and non-treated rabbit RBCs. The non-retained fraction was thus chosen to continue the purification by affinity chromatography on aBSM-sepharose. Several coupling methods were assayed and coupling percentage was determined for all affinity supports prepared (table 3 ). The best purification yield was achieved with $30.2 \%$ of aBSM coupled with cyanogen bromide, indicated that low ligand density was preferable in our case.

Table 2: Hemagglutination activity in LBL fractions from IEC

\begin{tabular}{|c|c|c|c|c|c|c|c|c|c|}
\hline \multirow[t]{3}{*}{ DEAE fraction } & \multicolumn{9}{|c|}{ Minimal agglutination concentration $\left(\mu \mathrm{g} \cdot \mu \mathrm{l}^{-1}\right)$} \\
\hline & \multicolumn{5}{|c|}{ Human erythrocytes } & \multicolumn{4}{|c|}{ Rabbit erythrocytes } \\
\hline & A & B & $\mathbf{0}$ & $\mathbf{T}$ & Tn & Non-T & $\mathbf{T}$ & $\mathbf{P}$ & $\mathbf{T} / \mathbf{P}$ \\
\hline Non-retained & - & - & - & - & 0.3 & 0.13 & 0.13 & 0.06 & 0.02 \\
\hline Eluted & 0.09 & 0.09 & 0.09 & 0.02 & 0.05 & 0.2 & 0.2 & 0.2 & 0.1 \\
\hline
\end{tabular}

-Non-agglutination detected, Non-T: Rabbit erythrocytes non-treated enzymatically; T: Trypsin treatment, P: Papain treatment; TP: Trypsin/Papain mixed treatment.

Table 3: Coupling of aBSM to sepharose 4B

\begin{tabular}{lll}
\hline Protocol & Coupling (\%) & aBSM (mg)/Sepharose 4B (ml) \\
\hline Cyanogen bromide-activated-Sepharose ${ }^{\circledR}$ 4B & 31.0 & 1.34 \\
ECH-Sepharose ${ }^{\circledR}$ 4B, Carbodiimide method & 53.4 & 0.69 \\
NHS-activated Sepharose ${ }^{\text {TM }}$ 4 Fast Flow & 57.1 & 3.12 \\
Sepharose ${ }^{\circledR}$ 4B, reductive amination method & 58.2 & 3.18 \\
\hline
\end{tabular}

The non-retained fraction was devoid of lectin activity, whilst the one eluted with $\mathrm{pH} 11.4$ presented high $\mathrm{Tn} / \mathrm{T}$ specific hemagglutination activity (fig. 2A, table 4). This fraction presented three protein bands at 28, 48 and $93 \mathrm{kDa}$ on SDS-PAGE in reducing and denaturing conditions (fig. 2B). The lectin activity is conserved with the high score using human and rabbit erythrocytes as observed for MLL and SSL $[15,16]$.
It was difficult to disaggregate the $93 \mathrm{kDa}$ specie, despite subjection to drastic reducing conditions such as 2 M DTT with heating at 100 ${ }^{\circ} \mathrm{C}$ for $15 \mathrm{~min}$. This behavior was observed previously for SBoL [25] and could be due to the strong alkaline environment obtained during the elution, where the disulfide bonds would be reduced [48] and can be rearranged $[49,50]$ forming non-native structures $[51$, $52]$, contributing to the formation of aggregates $[53,54]$.

Table 4: Hemagglutination activity in eluted fraction from affinity chromatography

\begin{tabular}{|c|c|c|c|c|c|c|c|c|c|}
\hline \multirow[t]{3}{*}{ Affinity chromatography } & \multicolumn{9}{|c|}{ Minimal concentration of protein $\left(\mu \mathrm{g} \cdot \mu \mathrm{l}^{-1}\right)$ to observe agglutination } \\
\hline & \multicolumn{5}{|c|}{ Human erythrocytes } & \multicolumn{4}{|c|}{ Rabbit erythrocytes } \\
\hline & $\mathbf{A}$ & B & $\mathbf{0}$ & $\mathbf{T}$ & Tn & Non-T & $\mathbf{T}$ & $\mathbf{P}$ & $\mathbf{T} / \mathbf{P}$ \\
\hline Fraction eluted with pH 11.4 (E) & - & - & - & 0.07 & 0.07 & 0.50 & 0.25 & 0.06 & 0.008 \\
\hline
\end{tabular}

-Non-agglutination detected, Non-T: Rabbit erythrocytes non-treated enzymatically; T: Trypsin treatment, P: Papain treatment; TP: Trypsin/Papain mixed treatment. 

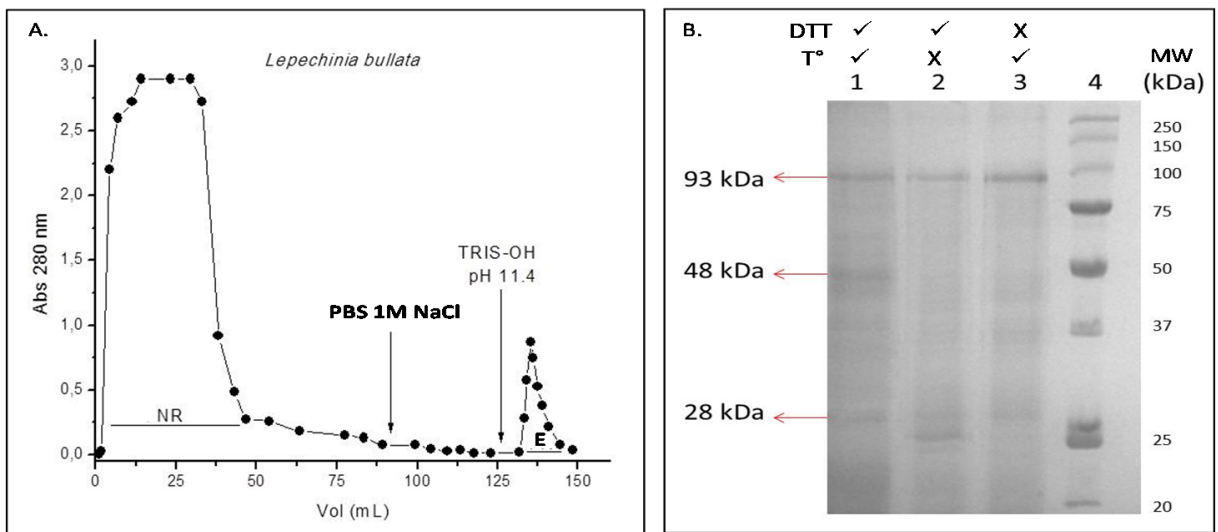

Fig. 2: Chromatographic affinity profile and SDS-PAGE of LBL. NR: Non-retained fraction. E: Eluted fraction. MW: Molecular weight standard. A. Affinity chromatography profile at $280 \mathrm{~nm}$. B. $12.5 \%$ Tris-Glycine SDS-PAGE with eluted LBL at pH 11.4 subjected to different reducing and denaturing conditions. Lane 1 . DTT $2 \mathrm{M}$ and heating at $100{ }^{\circ} \mathrm{C}$ for $15 \mathrm{~min}$; Lane 2. DTT $2 \mathrm{M}$ without heating; Lane 3. Heating to $100{ }^{\circ} \mathrm{C}$ for $15 \mathrm{~min}$, without adding DTT; Lane 4 . MW

When purified LBL was subjected to preparative electrophoresis in native conditions, two fractions were obtained which corresponded to monomer and dimer (or high molecular associations), the last form would be the most stable form of LBL (fig. 3A). Both fractions only showed one band at $28 \mathrm{kDa}$ on Tricine-SDS PAGE in reducing and non-reducing conditions (results not shown). Upon reducing conditions in preparative electrophoresis, LBL obtained one fraction only (fig. 3B) in which were observed two bands, one around $31 \mathrm{kDa}$ and another corresponding to a high molecular weight species in Tricine-SDS PAGE under reducing conditions. In otherwise, a single band at $31 \mathrm{kDa}$ without reducing agent but in the presence of SDS, was showed.

In denaturant conditions (fig. 3C) unusual behavior is observed in LBL, where there is a small proportion of a low molecular weight species and a greater proportion of two higher molecular weight associations. This result differs when the preparative electrophoresis is carried out in the presence of both SDS and DTT, since the monomeric form is not observed, but the high molecular weight species are still present (fig. 3D). In both fractions, a band around $28 \mathrm{kDa}$ was observed on Tricine-SDS PAGE in reducing and non-reducing conditions (results not shown). These results corroborate the absence of interchain disulfide bridges, as well as the presence of reduced intrachain disulfide bonds that cause an apparently higher molecular weight than that determined in native conditions. This behavior may be due to the reduced protein increases the Stokes radius and therefore migrate less in the gel, compared with the folded protein in which disulfide bonds are intact. MLL has three noncovalently linked subunits, under reducing conditions the $42 \mathrm{kDa}$ subunit migrates as a band of $46 \mathrm{kDa}$ [27]. The last fraction lost partially hemagglutinating activity because protein structure is affected by reducing conditions or probably, disulfide intrachain bridges were recombined in a different form regard native form.

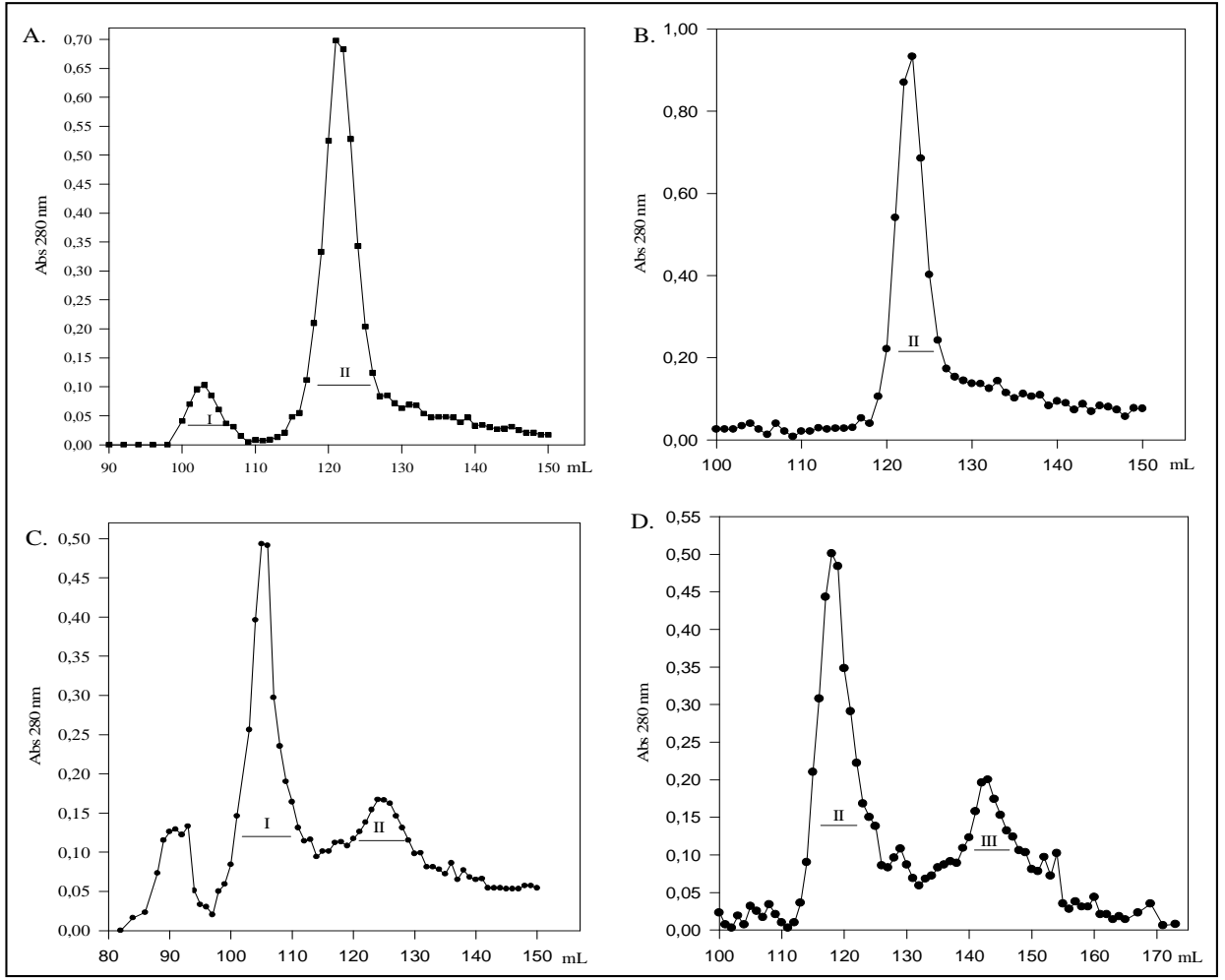

Fig. 3: Preparative SDS-PAGE electrophoresis of LBL. I: Monomeric, II: Dimeric, III: High molecular weight species from LBL. A. Native, B. Reducing (DTT) and heat, C. Denaturing (SDS) and heat and D. Denaturing, reducing (SDS, DTT) and heat conditions in preparative electrophoresis 
These results can be explained if consider that the protein has a highly hydrophobic structure with intracatenary disulfide bridges. Studies did on heat effect on $\beta$-globulin have shown the formation of aggregates by disulfide bridges exchange and the dimer stabilization by hydrophobic interaction of SDS [53,54]. Taking into consideration the ensemble of results on the determination of LBL size, we propose that the lectin is associated as a dimer and as a high molecular weight species consisting of non-covalently associated monomers $(28 \mathrm{kDa})$. Lamiaceae lectins corresponds to non-covalently linked subunits, as seen in SBoL [25] and MLL [15, 26, 27], or dimers linked by disulfide bonds like for SSL [14] and Glechoma hederacea agglutinin (Gleheda) [17].
Fourth consecutive extractions steps were sufficient for LBL purification since a low lectin activity was detected in the fourth extract treated with Pectinex®. 1339-fold purification was achieved (table 5) which is lower than SBoL (2823-fold) [25] and significantly higher than that for SSL (87-fold) [14]. It corresponds to a lectin amount of $6.2 \mathrm{mg} / 100 \mathrm{~g}$ seeds which is in the range of yield obtained for other lectins as SBoL (18-20 mg/100 g seeds) [25], MLL (15-20 mg/100g seeds) [26], SSL (5 mg/100 g seeds) [14] and Gleheda $(10 \mathrm{mg} / 100 \mathrm{~g}$ leaves) [17]. The LBL is insoluble at concentrations higher than $1.0 \mathrm{mg} \cdot \mathrm{ml}^{-1}$ in PBS, while SBoL is soluble at $1.7-2 \mathrm{mg} \cdot \mathrm{ml}^{-1}[25]$.

Table 5: Lectin purification from Lepechinia bullata seeds

\begin{tabular}{|c|c|c|c|}
\hline Purification step ${ }^{1}$ & Protein $(\mathrm{mg} / \mathrm{ml})^{2}$ & SAA $^{3}$ & Purification (fold) \\
\hline 1. First extract & $2.14 \pm 0.1$ & - & - \\
\hline 2. Second extract & $0.81 \pm 0.08$ & - & - \\
\hline 3. Third extract & $0.75 \pm 0.08$ & - & - \\
\hline 4. Fourth extract & $0.62 \pm 0.05$ & - & - \\
\hline Pool of extracts & $1.11 \pm 0.05$ & 3.6 & 1 \\
\hline 5. DEAE (non-retained fraction) & $1.36 \pm 0.1$ & 5.9 & 1.6 \\
\hline 6. Affinity chromatography & $0.43 \pm 0.03$ & 4822 & 1339 \\
\hline
\end{tabular}

$150 \mathrm{~g}$ of seeds extracted with PBS-5 mmol thiourea buffer. ${ }^{2}$ Determined by the micro-Kjeldahl method. ${ }^{3}$ SAA is defined as the minimal dilution required for hemagglutination. This assay was done with enzyme-treated A+ erythrocytes to expose Tn antigen [40]. Values are means \pm SD of three determinations.

Previous studies reported that Lamiaceae lectins obtained from $S$. sclarea [14, 16], Glechoma hederacea [17], S. palifolia [22], Hyptis mutabilis [22], S. bogotensis [24], Moluccella laevis [25] and S. miltiorrhiza [55] recognize Tn antigen only.

However, in this case, hemagglutination activity was observed with both $\mathrm{T}$ and $\mathrm{Tn}$ human erythrocytes. LBL recognized rabbit RBCs enzymatically treated and non-treated but was unable to agglutinate human erythrocytes from A, B, O donors and equine or bovine RBCs.

The required minimum lectin concentration was $70 \mu \mathrm{g} \cdot \mathrm{ml}^{-1}$ in $\mathrm{Tn}$ human erythrocites and $8 \mu \mathrm{g} \cdot \mathrm{ml}^{-1}$ in rabbit RBCs treated with trypsin and papain, which is higher than the one reported for SBoL $\left(0.17 \mu \mathrm{g} \cdot \mathrm{ml}^{-1}\right)$ [25], S. miltiorrhiza lectin (SML) (1.99 and $3.91 \mu \mathrm{g} \cdot \mathrm{ml}^{-1}$ ) in mouse and rabbit erythrocytes trypsin-treated respectively, [55] and Gleheda $\left(0.22 \mu \mathrm{g} \cdot \mathrm{ml}^{-1}\right)$ [17].

LBL presented a carbohydrate content of $13.4 \%$, which is in accordance with the 10-15\% found in other Lamiaceae lectins [22] (table 6). Since carbohydrates are usually conserved in plant proteins, the glycan present on LBL should then be similar to Lamiaceae lectins studied to date $[22,25]$.

Similarly, LBL is also basic since it pI is near to 8.5 , which is comparable with the one reported for SBoL (8.8 and 8.6) and SSL (8.8 and 8.0) (table 6).

Table 6: Molecular properties of $L$. bullata and other lamiaceae lectins

\begin{tabular}{|c|c|c|c|c|c|c|}
\hline \multirow[t]{2}{*}{ Lamiaceae lectins } & \multirow[t]{2}{*}{ Recognition } & \multicolumn{2}{|c|}{ Molecular weight (kDa) } & \multirow{2}{*}{$\begin{array}{l}\text { Carbo- } \\
\text { hydrates (\%) }\end{array}$} & \multirow[t]{2}{*}{ pI } & \multirow[t]{2}{*}{ Disulfide bonds } \\
\hline & & Native & Subunits & & & \\
\hline Lepechinia bullata & T, Tn, Rabbit RBCs & N. D & $93^{*} / /^{* *} 48^{*}, 28^{*} / * *$ & 13.4 & 8.5 & Intrachain \\
\hline Glechoma hederacea [17] & $\mathrm{T}, \mathrm{Tn}$ & $85^{+} 80-93^{++}$ & 26,28 & 10 & N. D. & Interchain/Intrachain \\
\hline Hyptis mutabilis [23] & $\operatorname{Tn}$ & N. D & 55,51 & 27.7 & 7.5 and 6.7 & N. D \\
\hline $\begin{array}{l}\text { Molucella laevis }[15,26,27 \text {, } \\
38]\end{array}$ & $\mathrm{Tn}$ & 130 & $26,28,42$ & 10 & N. D. & Interchain/Intrachain \\
\hline Salvia bogotensis [25] & $\mathrm{Tn}$ & 72 & 38.7 & 16 & 8.8-8.6 & Intrachain \\
\hline Salvia miltiorrhiza [55] & $\begin{array}{l}\text { Rabbit and mouse } \\
\text { RBCs }\end{array}$ & N. D & 26.3 & N. D & 4.76 & N. D \\
\hline Salvia palifolia [23] & $\operatorname{Tn}$ & N. D & 58,64 & 23.8 & 7.4 and 6.8 & N. D \\
\hline Salvia sclarea $[14,16]$ & $\mathrm{Tn}$ & 50 & 35 & 15 & 8.8 and 8.0 & Interchain \\
\hline
\end{tabular}

N. D. Not determined. ${ }^{*}$ Reduced protein. ${ }^{* *}$ Unreduced protein. + Gel filtration on a superose column. ${ }^{++}$Sedimentation velocity analysis.

\section{Carbohydrate-binding}

Among the assayed sugars and glycoproteins, only GalNAc (75 mmol) and fetuin $(25 \mathrm{mmol})$ completely inhibited the hemagglutination by LBL from Tn human and rabbit erythrocytes respectively (table 7).

Hemagglutination from SBoL, SSL and MLL was inhibited by GalNAc concentrations of $37.5,0.1$ and $0.01 \mathrm{mmol}$ respectively [14, 15, 27]. Gleheda inhibition assays with trypsin-treated rabbit erythrocytes revealed $50 \%$ inhibition at $25 \mathrm{mmol}$ GalNAc [17]. Fetuin is a highly sialylated glycoprotein, which presents both $\mathrm{N}$ and O-glycosylations [56]. In the latter case, the $\mathrm{T}$ antigen is sialylated but becomes fully exposed after desialylation with dilute acids [57]. Some ends in fetuin may be desialylated, and thus inhibited the agglutination by LBL of rabbit erythrocytes, indicating the presence and the recognition of $\mathrm{Tn}$ antigen.

A comparison of sugar inhibitions in several lectins from Lamiaceae, including LBL, is shown in table 7. 
Table 7: Comparison of sugar inhibitions in Lamiaceae lectins

\begin{tabular}{|c|c|c|c|}
\hline Lamiaceae lectins origin & Inhibitor sugar & Concentration & Model used to assay \\
\hline \multirow[t]{4}{*}{ L. bullata } & GalNAc & $75 \mathrm{mmol}$ & Human erythrocytes A+treated enzymatically to expose Tn antigen \\
\hline & aMSB & $0.2 \mu \mathrm{g} \cdot \mu \mathrm{l}^{-1}$ & HeLa and MCF-7 tumoral cell lines \\
\hline & aMSO & $0.42 \mu \mathrm{g} \cdot \mu \mathrm{l}^{-1}$ & \\
\hline & Fetuin & $25 \mathrm{mmol}$ & Rabbit erythrocytes treated with trypsin and papain \\
\hline \multirow[t]{3}{*}{ S. bogotensis [25] } & GalNAc & $37.5 \mathrm{mmol}$ & Human erythrocytes $A^{+}$treated enzymatically to expose Tn antigen \\
\hline & MSO & $0.019 \mathrm{mmol}$ & \\
\hline & aMSB & $0.008 \mathrm{mmol}$ & \\
\hline \multirow[t]{4}{*}{ S. sclarea [14] } & GalNAc & $0.1 \mathrm{mmol}$ & Human erythrocytes $A^{+}$treated enzymatically to expose Tn antigen \\
\hline & Gal & $75 \mathrm{mmol}$ & \\
\hline & aMSB & $0.02 \mathrm{mmol}$ & \\
\hline & MSB & $0.04 \mathrm{mmol}$ & \\
\hline \multirow[t]{3}{*}{ Moluccella laevis [26] } & GalNAc & $2.0 \mu \mathrm{g} \cdot \mathrm{ml}^{-1}$ & Human erythrocytes $\mathrm{A}^{\mathrm{MM}}$ and $\mathrm{O}^{\mathrm{NN}}$ \\
\hline & MSO & $0.1 \mu \mathrm{g} \cdot \mathrm{ml}^{-1}$ & \\
\hline & aMSO & $0.003 \mu \mathrm{g} \cdot \mathrm{ml}^{-1}$ & \\
\hline Glechoma hederacea [17] & GalNAc & $25 \mathrm{mmol}$ & Rabbit erythrocytes treated with trypsin \\
\hline
\end{tabular}

${ }^{*}$ Expressed as the concentration of free terminal GalNAc

\section{Effect of temperature and cation}

LBL hemagglutination began to diminish above $37 \pm 0.5^{\circ} \mathrm{C}$, and was completely abolished at $60^{\circ} \mathrm{C}$. Precipitation of the lectin occurred at temperatures above $80{ }^{\circ} \mathrm{C}$ because of thermal denaturation. The lectin's thermal stability which is similar to SSL, appears to be very labile as reported by Piller et al. [14]. Other lectins as Gleheda and SBoL retain $50 \%$ of their activity at $56^{\circ} \mathrm{C}[17,25]$. The denaturation temperature could not be determined by TSA perhaps as a result of lectin aggregation or non-binding of the dye in the absence of exposed hydrophobic residues, corroborating bands obtained in SDS-PAGE. All tested concentrations led to a similar result.

LBL was active in PBS or $1 \% \mathrm{NaCl}$ at $\mathrm{RT}$ without requiring metals addition, but in presence of EDTA lectin's activity decreased by $50 \%$, indicating it depends on the presence of divalent ions. Other lectins such as some of the Legume present the same behaviour [30,58]. These proteins are composed of two or four identical subunits with a molecular weight between 25 and $30 \mathrm{kDa}$, each of which contains a binding site for the $\mathrm{Ca}^{2+}, \mathrm{Mn}^{2+}$ and/or $\mathrm{Mg}^{2+}$ metals in nearby to "carbohydrate bind site" [59]. A typical example are lectins from Viceae and Diocleae tribes, specially Concanavalin A [60]. Maybe in the structure of LBL, the interaction between ions and the protein is weak, or the ions are exposed and are therefore easily removed by the action of chelating agents. The lectin's activity depends on $\mathrm{Ca}^{+2}$ and $\mathrm{Mn}^{+2}$ binding to the native protein, as well as the presence of intact disulphide bridges as observed for SSL and SBoL $[14,25]$.

The amino acid composition (table 8) showed a high content of glycine, lysine, histidine and hydroxy amino acids. The protein contains methionine, unusual residue among legume lectins and some Lamiaceae. The five cysteine residues apparently form intrachain disulphide bonds, given that reduced as well as nonreduced samples showed almost the same bands by SDS-PAGE. Something similar occurs in Gleheda, where there are three cysteines, two of which forming one intrachain disulfide bridge [17]. According to Alperin et al. [26], no disulfide bond is present in 26 $\mathrm{kDa}$ subunit from MLL, whereas an interchain disulfide bond links the two subunits for SSL and Gleheda $[14,16,17]$.

Considering the pI of LBL of 8.5, a great proportion of Asx and Glx should correspond to asparagine and glutamine respectively, and there is also a great content of lysine and histidine to explain its basic characterr.

Table 8: Amino acid composition of lectins from L. bullata and other lamiaceae species

\begin{tabular}{|c|c|c|c|c|c|c|c|}
\hline \multirow{2}{*}{$\begin{array}{l}\text { Amino acid } \\
\text { (AA) }\end{array}$} & \multicolumn{3}{|l|}{ LBL $^{1}$} & \multirow{2}{*}{$\begin{array}{l}\text { SBoL } 5 \\
\text { Residues in } \\
\text { polipeptide chain }\end{array}$} & \multirow{2}{*}{$\begin{array}{l}\text { SSL6 }^{6} \\
\text { Calculated } \\
\text { residues }\end{array}$} & \multirow{2}{*}{$\begin{array}{l}\text { SML7 } \\
\text { Residues in } \\
\text { polipeptide chain }\end{array}$} & \multirow{2}{*}{$\begin{array}{l}\text { Gleheda }^{8} \\
\text { Residues in } \\
\text { polipeptide chain }\end{array}$} \\
\hline & $\begin{array}{l}\text { mg AA/100 g } \\
\text { protein }\end{array}$ & $\begin{array}{l}\text { Calculated } \\
\text { residues }\end{array}$ & $\begin{array}{l}\text { Nearest } \\
\text { integer }^{4}\end{array}$ & & & & \\
\hline Ala (A) & 2.44 & 8.3 & 8 & 36 & 75.9 & 21 & 16 \\
\hline Cys (C) & $2.07^{2}$ & 4.9 & 5 & 4 & 1.2 & 0 & 3 \\
\hline Phe (F) & 9.08 & 14.9 & 15 & 4 & 36.6 & 15 & 11 \\
\hline Gly (G) & 8.63 & 36.7 & 37 & 92 & 126.8 & 22 & 20 \\
\hline His $(\mathrm{H})$ & 10.79 & 19.1 & 19 & 4 & 9.4 & 5 & 9 \\
\hline Ile (I) & 4.48 & 9.6 & 10 & 6 & 20.6 & 13 & 16 \\
\hline Lys $(\mathrm{K})$ & 10.61 & 20.1 & 20 & 21 & 7.8 & 4 & 14 \\
\hline Leu (L) & 7.12 & 15.2 & 15 & 10 & 27 & 13 & 15 \\
\hline Met (M) & $1.05^{2}$ & 1.7 & 2 & 0 & 1.3 & 2 & 4 \\
\hline Pro (P) & 2.88 & 7.2 & 7 & 13 & 17.7 & 10 & 11 \\
\hline $\operatorname{Arg}(\mathrm{R})$ & 4.30 & 6.7 & 7 & 3 & 13.2 & 8 & 6 \\
\hline Ser (S) & 4.39 & 12.2 & 12 & 60 & 73.2 & 22 & 20 \\
\hline Thr (T) & 4.37 & 10.4 & 10 & 13 & 66.2 & 26 & 19 \\
\hline Val (V) & 4.85 & 11.9 & 12 & 10 & 43.9 & 25 & 21 \\
\hline $\operatorname{Trp}^{3}(\mathrm{~W})$ & 7.78 & 10.1 & 10 & 9 & N. D. & 3 & 5 \\
\hline Tyr (Y) & 5.70 & 8.4 & 8 & 5 & 12.4 & 8 & 4 \\
\hline Asx $(D+N)$ & 6.85 & 14.4 & 14 & 15 & 58.6 & 27 & 32 \\
\hline Asp (D) & N. D. & N. D. & N. D. & N. D. & N. D. & 14 & 19 \\
\hline Asn (N) & N. D. & N. D. & N. D. & N. D. & N. D. & 13 & 13 \\
\hline Glx $(E+Q)$ & 5.54 & 10.4 & 10 & 42 & 31.2 & 22 & 10 \\
\hline Glu (E) & N. D. & N. D. & N. D. & N. D. & N. D. & 7 & 5 \\
\hline Gln (Q) & N. D. & N. D. & N. D. & N. D. & N. D. & 15 & 5 \\
\hline
\end{tabular}

N. D. Non determined. ${ }^{1}$ Calculations based on a $\mathrm{Mr}=28000 \mathrm{~g}$ with $13,4 \%$ carbohydrate. ${ }^{2}$ Determined as $\mathrm{MetSO}_{2}$ and $\mathrm{CySO}_{3} .{ }^{3} \mathrm{Determined}$ spectrophotometrically. ${ }^{4}$ Residues per polypeptide chain. ${ }^{5}$ Taken from Vega and Pérez [25]. ${ }^{6}$ Calculated from Medeiros et al. [16]. $\mathrm{Mr}=60000 \mathrm{Da} .{ }^{7}$ Based in Wenping et al. [55]. ${ }^{8}$ Based in Wang et al. [17]. 


\section{LBL interaction with HeLa and MCF-7 Cells}

Considering LBL's ability to specifically recognize the $\mathrm{Tn} / \mathrm{T}$ antigen, specific recognition of Tn determinant was corroborated by CELISA, in which biotinylated LBL strongly bound to HeLa Cells (fig. 4A). $\mathrm{VVB}_{4}$ was used as a control due to its well-established Tn specificity [28]. A strong specific binding towards the two cell lines was revealed in the same extend than $\mathrm{VVB}_{4}$ just using $2.5 \mu \mathrm{g}$ of each lectin. $50 \%$ of interaction was inhibited using $492 \mu \mathrm{g}$ of GalNAc, 0.42 $\mu \mathrm{g}$ of OSM (13.8-15\% GalNAc content) and $0.2 \mu \mathrm{g}$ of aBSM $(18 \%$ GalNAc content). SBoL binding to MCF-7 (breast cancer), HeLa (cervix cancer) and BHK (kidney fibroblasts) cell lines in periodontal tissue and mice skin fibroblast primary cultures, has been described previously [24]. Osinaga et al. [61] detected Tn antigen by using a monoclonal antibody (83D4) and the inhibition assays were performed by using lectins as inhibitors, the best inhibitor was $\mathrm{VVB}_{4}$. Therefore, lectins are valuable tools for the detection of antigen $\mathrm{Tn}$.

\section{Anti-SBoL interaction with LBL}

$5 \mu \mathrm{g}$ of Anti-SBoL IgG were necessary for LBL recognition (fig. 4B). These results indicate that the two proteins could have similarity structural and sequence since the antibody almost identically recognizes them. Similar results were obtained using anti-SBoL IgY in order to detect interaction with Salvia hispanica, L. bullata and Leguminosae lectins; a somewhat lesser interaction was observed with LBL showing this lectin lesser structural homology with SBoL [62].

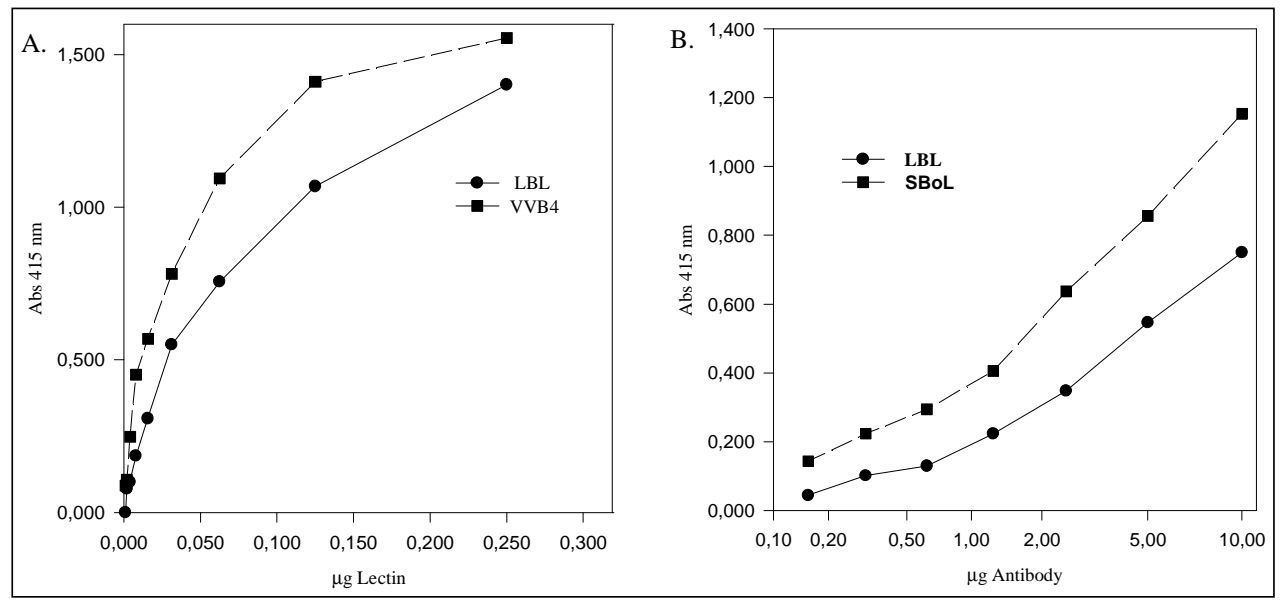

Fig. 4: Interaction of LBL with Cell line Hela and anti-SBoL. A. Tn detection in HeLa Cell line. B. Anti-SBoL antibody interaction with LBL by ELLA

\section{CONCLUSION}

The lectin's specificity and high affinity for the $\mathrm{T}$ and $\mathrm{Tn}$ antigens, commonly found in tumor cells, makes this protein a useful tool for immuno-histochemical and cellular studies. Our future aim is to carry out structural studies on Lamiaceae lectins to know about interaction lectin-T/Tn antigens and how this molecule could be used like a tool in clinical assays. To date, this field remains unexplored.

\section{ACKNOWLEDGEMENT}

The authors are grateful for the valuable contributions and teachings of Professor Gerardo Pérez (R. I. P), former leader of the Protein Research Group.

The Department of Chemistry at the Universidad Nacional- Bogotá, Colombia and COLCIENCIAS, provided financial support with project "Lamiaceae structure Lectins" number 110148925106. JL Fernández Alonso also appreciates the support of the CGL 2010-19747 project of the Spanish National Research Council (RJB-CSIC), which facilitated visits to Colombia. The authors are grateful for the support of molecular and structural glycobiology team CERMAV, CNRS, University Grenoble Alpes, France.

\section{AUTHORS CONTRIBUTION}

\begin{tabular}{|c|c|c|c|c|c|}
\hline Author name & $\begin{array}{l}\text { Research conception/ } \\
\text { design }\end{array}$ & Data acquisition & $\begin{array}{l}\text { Data analysis/ } \\
\text { Interpretation }\end{array}$ & Manuscript preparation & Final approval \\
\hline Andrea Wilches-Torres & $\mathrm{X}$ & $\mathrm{X}$ & $\mathrm{X}$ & $\mathrm{X}$ & \\
\hline José Rojas-Caravallo & $\mathrm{X}$ & $\mathrm{X}$ & $\mathrm{X}$ & & \\
\hline Edilma Sanabria & $\mathrm{X}$ & $\mathrm{X}$ & $\mathrm{X}$ & & \\
\hline Edgar Reyes-Montaño & & & $\mathrm{X}$ & $\mathrm{X}$ & \\
\hline José Luis Fernández-Alonso & & & $\mathrm{X}$ & $\mathrm{X}$ & $\mathrm{X}$ \\
\hline Annabelle Varrot & & $\mathrm{X}$ & $\mathrm{X}$ & $\mathrm{X}$ & $\mathrm{X}$ \\
\hline Anne Imberty & & $\mathrm{X}$ & $\mathrm{X}$ & $\mathrm{X}$ & $\mathrm{X}$ \\
\hline Nohora Vega & $\mathrm{X}$ & $\mathrm{X}$ & $\mathrm{X}$ & $\mathrm{X}$ & $\mathrm{X}$ \\
\hline
\end{tabular}

\section{CONFLICT OF INTERESTS}

Declared none

\section{REFERENCES}

1. Rudiger H, Gabius HJ. The history of lectinology. In: Gabius HJ. editor. The Sugar Code Fundamentals of glycosciences. Weinheim, Germany: Wiley; 2009. p. 261-8.

2. Ghazarian H, Idoni B, Oppenheimer SB. A glycobiology review: carbohydrates, lectins, and implications in cancer therapeutics. Acta Histochem 2011;113:236-47.
3. Springer GF. T and Tn, general carcinoma autoantigens. Science 1984;224:1198-207.

4. Lisowska E. Tn antigens and their significance in oncology. Acta Biochim Pol 1995;42:11-8.

5. Kishikawa T, Ghazizadeh M, Sasaki Y, Springer GF. The specific role of $\mathrm{T}$ and $\mathrm{Tn}$ tumour-associated antigens in adhesion between a human breast carcinoma cell line and a normal human breast epithelial cell line. Jpn J Cancer Res 1999;90:326-32.

6. Ju T, Otto VI, Cummings RD. The Tn antigen-structural simplicity and biological complexity. Angew Chem Int Ed Engl 2011;50:1770-91. 
7. Sylvain J, Videira PA, Philippe D. Sialyl-tn in cancer: (How) did we miss the target? Biomolecules 2012;2:435-66.

8. Munkley J. The role of sialyl-tn in cancer. Int J Mol Sci 2016;17:275.

9. Rougé P, Peumans WJ, Van Damme EJM, Barre A, Singh T, Wu $\mathrm{JH}$, et al. Glycotope structures and intramolecular affinity factors of plant lectins for $\mathrm{Tn} / \mathrm{T}$ antigens In: Wu A. editor. The Molecular Immunology of complex carbohydrates. 3rd ed. Boston: Springer; 2011. p. 143-54.

10. Bird GWG, Wingham J. Haemagglutinins from Salvia. Vox Sang 1974;26:163-6.

11. Bird GWG, Wingham J. More Salvia agglutinins. Vox Sang 1976;30:217-9.

12. Bird GWG, Wingham J. Yet more Salvia agglutinins. Vox Sang 1977;32:121-2.

13. Kitagaki-Ogawa H, Matsumoto I, Seno N, Takahashi N, Endo S, Arata Y. Characterization of the carbohydrate moiety of Clerodendron trichotomum lectins: its structure and reactivity toward plant lectins. Eur J Biochem 1986;161:779-85.

14. Piller V, Piller F, Cartron JP. Isolation and characterization of an $\mathrm{N}$-acetylgalactosamine specific lectin from Salvia sclarea seeds. J Biol Chem 1986;261:14069-75.

15. Lis H, Latter H, Adar R, Sharon N. Isolation of two blood type A and $\mathrm{N}$ specific isolectins from Moluccella laevis seeds. FEBS Lett 1988;233:191-5.

16. Medeiros A, Bianchi S, Calvete JJ, Balter H, Bay S, Robles A, et al. Biochemical and functional characterization of the $\mathrm{Tn}$ specific lectin from Salvia sclarea seeds. Eur J Biochem 2000;267:1434-40.

17. Wang $\mathrm{W}$, Peumans $\mathrm{WJ}$, Rougé $\mathrm{P}$, Rossi C, Proost $\mathrm{P}$, Chen J, et al. Leaves of the Lamiaceae species Glechoma hederacea (ground ivy) contain a lectin that is structurally and evolutionary related to the legume lectins. Plant J 2003;33:239-304.

18. Fernández -Alonso JL, Vega N, Filgueira JJ, Pérez G. Lectin prospecting in Colombian Labiatae. A systematic-ecological approach. Biochem Syst Ecol 2003;31:617-33.

19. Pérez G, Vega N, Fernández-Alonso JL. Prospeccion de lectinas en especies de labiadas colombianas. Un enfoque sistematicoecologico-II. Caldasia 2006;28:179-95.

20. Fernández -Alonso JL, Vega N, Pérez G. Lectin prospecting in colombian Labiatae. A systematic ecological approach-III. Mainily exotic species (cultivated or naturalised). Caldasia 2009;31:227-45.

21. Fernández-Alonso JL, Rivera-Diaz O. Las Labiadas. In: Garcia N, Galeano G. editors. Libro Rojo de Plantas de Colombia Volumen 3 Serie Libros Rojos de Especies Amenazadas de Colombia. Bogota, Colombia: Instituto Alexander von Humboldt-Instituto de Ciencias Naturales de la Universidad Nacional de ColombiaMinisterio de Ambiente, Vivienda y Desarrollo Territorial; 2006. p. 385-582.

22. Pérez G, Vega N. Lamiaceae lectins. Funct Plant Sci Biotechnol 2007;1:288-99.

23. Filgueira-Duarte JJ, Pérez G. Producción de lectinas Tnespecíficas obtenidas de Salvia palifolia y Hyptis mutabilis por variación somaclonal celular. Rev Fac Ciencias Basicas Univ Mil Nueva Granada 2013;9:134-41.

24. Vega N. Caracterizacion bioquimica, funcional y biologica de la lectina de Salvia bogotensis y evaluación de su aplicación para la detección del antigeno Tn. Universidad Nacional de Colombia; 2004.

25. Vega N, Pérez G. Isolation and characterisation of a Salvia bogotensis seed lectin specific for the $\mathrm{Tn}$ antigen. Phytochemistry 2006;67:347-55.

26. Alperin DM, Latter $\mathrm{H}$, Lis $\mathrm{H}$, Sharon $\mathrm{N}$. Isolation by affinity chromatography and gel filtration in $8 \mathrm{M}$-urea, of an active subunit from the anti-(blood-group $\mathrm{A}+\mathrm{N}$ )-specific lectin of Moluccella laevis. Biochem J 1992;285:1-4.

27. Lis $\mathrm{H}$, Sharon N. Moluccella laevis lectin-an unusual protein with a unique specificity. Trends Glycosci Glycotechnol 1994;6:65-74.

28. Tollefsen SE, Kornfeld R. The B4 lectin from Vicia villosa seeds interacts with $\mathrm{N}$-Acetylgalactosamine residues $\alpha$-linked to serine or threonine residues in cell surface glycoproteins. J Biol Chem 1983;258:5172-6.
29. Pérez G, Hernandez M, Mora E. Isolation and characterization of a lectin from the seeds of Dioclea lehmanni. Phytochemistry 1990;29:1745-9.

30. Pérez G. Isolation and characterization of a lectin from the seeds of Erythrina edulis. Phytochemistry 1984;23:1229-32.

31. Smith PK, Krohn RI, Hermanson GT, Mallia AK, Gartner FH, Provenzano MD, et al. Measurement of protein using bicinchoninic acid. Anal Biochem 1985;150:76-85.

32. Almanza AM. Purificación y caracterización parcial de la lectina presente en las semillas de Galactia lindenii. Universidad Nacional de Colombia; 1999.

33. Van Driessche E, Beeckmans S, Dejaegere R, Kanarek L. Thiourea: the antioxidant of choice for the purification of proteins from phenol-rich plant tissues. Anal Biochem 1984;141:184-8.

34. Hermanson GT, Mallia AK, Smith PK. Immobilized affinity ligand techniques. 1st ed. San Diego: Academic Press; 1992.

35. Laemmli UK. Cleavage of structural proteins during the assembly of the head of bacteriophage-T4. Nature 1970;227:680-5.

36. Schägger H, von Jagow G. Tricine-sodium dodecyl sulphatepolyacrylamide gel electrophoresis for the separation of proteins in the range from 1 to $100 \mathrm{kDa}$. Anal Biochem 1987;166:368-79.

37. Sánchez M. Estandarización de las condiciones de separación de las subunidades que constituyen las lectinas presentes en las semillas de Salvia bogotensis. Universidad Nacional de Colombia; 2003.

38. Duk M, Lisowska E, $\mathrm{Wu} \mathrm{JH}, \mathrm{Wu}$ AM. The biotin/avidin-mediated microtiter plate lectin assay with the use of chemically modified glycoprotein ligand. Anal Biochem 1994;221:266-72.

39. Vega N. Detección, purificación y caracterización parcial de la lectina presente en las semillas del genero Salvia. Universidad Nacional de Colombia; 1997.

40. Hirohashi S, Clausen H, Yamada T, Shimosato Y, Hakomori S. Blood group A cross-reacting epitope defined by monoclonal antibodies NCC-LU-35 and-81 expressed in cancer of blood group 0 or B individuals: its identification as Tn antigen. Proc Natl Acad Sci U S A 1985;82:7039-43.

41. O’Donoghue M, Allard P, Ferlinz A, Verheyde J, Warrington K, Nhiri $\mathrm{N}$, et al. Protein thermal shift assay using applied biosystems rel time PCR systems. In: Life Technologies Corporation; 2009.

42. Bollag D, Edelstein S. Isoelectric focusing (IFC). In: Protein Methods. 4th ed. New York: Wiley-Liss; 1991. p. 162-74.

43. Wu AM, Duk $M$, Lin $M$, Broadberry $R E$, Lisowska $E$. Identification of variant glycophorins of human red cells by lectinoblotting: application to the MiIII variant that is relatively frequent in the taiwanese population. Transfusion 1995;35:571-6.

44. Walker KW, Llull R, Balkian GK, Ko SH, Flores KM, Ramsamooj $\mathrm{R}$, et al. Rapid and sensitive cellular enzyme-linked immunoabsorbent assay (CELISA) for the detection and quantitation of antibodies against cell surface determinants. J Immunol Methods 1992;154:121-30.

45. Acosta C, Carpio C, Vilcacundo R, Carrillo W. Identification of proteins isolated from amaranth (Amaranthus caudatus) by sodium dodecyl sulphate-polyacrylamide gel electrophoresis with water and $\mathrm{NaCl} 0.1 \mathrm{M}$ solvents. Asian J Pharm Clin Res 2016;9:9-12.

46. Poveda T, Vilcacundo R, Carpio C, Carrillo W. Analysis of sesame proteins isolate (Sesamum Indicum L) with water and salt treatment. Asian J Pharm Clin Res 2016;9:1-4.

47. Bisht A, Thapliyal M, Singh A. Screening and isolation of antibacterial proteins/peptides from seeds of millets. Int J Curr Pharm Rev Res 2016;8:96-9.

48. Ryle BYAP, Sanger F. Disulphide interchange reactions. Biochem J Aug 1955;60:535-40.

49. Ryle AP, Sanger F, Smith LF, Kitai R. The disulfide bonds of insulin. Biochem J 1955;60:541-56.

50. Spackman DH, Stein WH, Moore S. The disulphide bonds of ribonuclease. J Biol Chem 1960;235:648-59.

51. Goldenberg DP. Native and non-native intermediates in the BPTI folding pathway. Trends Biochem Sci 1992;17:257-61. 
52. Qin M, Wang W, Thirumalai D. Protein folding guides disulfide bond formation. Proc Natl Acad Sci 2015;112:11241-6.

53. Havea P, Carr AJ, Creamer LK. The roles of disulphide and noncovalent bonding in the functional properties of heat-induced whey protein gels. J Dairy Res 2004;71:330-9.

54. Considine T, Patel HA, Singh H, Creamer LK. Influence of binding of sodium dodecyl sulfate, all-trans-retinol, palmitate, and 8-anilino1-naphthalenesulfonate on the heat-induced unfolding and aggregation of $\alpha$-lactoglobulin B. Food Chem 2005;53:3197-205.

55. Wenping $H$, Limin $H$, Zhezhi W. Molecular cloning and expression of a novel gene related to legume lectin from Salvia miltiorrhiza Bunge. Afr J Biotechnol 2015;14:2234-43.

56. Baenziger JU, Fiete D. Structure of the complex oligosaccharides of fetuin. J Biol Chem 1979;254:789-95.

57. Terra VS, Homer KA, Rao SG, Andrew PW, Yesilkaya H. Characterization of novel B-galactosidase activity that contributes to glycoprotein degradation and virulence in Streptococcus pneumoniae. Infect Immun 2010;78:348-57.
58. Pérez G. Purification and characterization of a lectin from the seeds of Erythrina costaricensis. Int J Biochem Cell Biol 1995;27:857-63.

59. Wah DA, Romero A, Gallego del Sol F, Cavada BS, Ramos MV, Grangeiro TB, et al. Crystal structure of native and $\mathrm{Cd} / \mathrm{Cd}$ substituted Dioclea guianensis seed lectin. A novel manganesebinding site and structural basis of dimer-tetramer association. J Mol Biol 2001;310:885-94.

60. Hardman KD, Ainsworth CF. Structure of concanavalin A at 2.4Ang resolution. Biochemistry 1972;11:4910-9.

61. Osinaga E, Pancino G, Porchet N, Berois N, De Cremoux P, Mistro D, et al. Analysis of a heterogeneous group of human breast carcinoma-associated glycoproteins bearing the $\mathrm{Tn}$ determinant. Breast Cancer Res Treat 1994;32:139-52.

62. Vega N, Murcia H, Pérez G. Characterization of Salvia bogotensis anti-lectin IGYs and their application in immunochemical studies involving Tn detection. Rev Colomb Quimica 2009;38:363-77. 